\title{
Socio-economic characteristics of dairy production in the selected areas of Ethiopian central highlands
}

\author{
Abebe Bereda ${ }^{1,3^{*}}$, Zelalem Yilma ${ }^{2}$, Mitiku Eshetu ${ }^{3}$, Mohammed Yousuf ${ }^{3}$ and Getenet Assefa ${ }^{4}$ \\ ${ }^{1}$ Department of Animal Sciences, Debre Berhan University, Debre Birhan, Ethiopia \\ ${ }^{2}$ Land O'Lakes IDF - PAID Ethiopia Program, Ethiopia \\ ${ }^{3}$ School of Animal and Range Sciences, Haramaya University, Ethiopia \\ ${ }^{4}$ Ethiopian Institute of Agricultural Research, Addis Ababa, Ethiopia.
}

Received 18 April, 2017: Accepted 23 May, 2017

\begin{abstract}
A study was carried out to assess dairy production practices in eight selected areas of the Ethiopian central highlands. Overall, 320 smallholder farmers (40 from each of 8 study sites) were randomly selected for individual interviews using a semi-structured questionnaire. Dairying (43\%) was reported to be a major source of income for farm household. The major feed sources for dairy cattle includes grazing on natural pasture $(62 \%)$, grass hay $(94 \%)$, crop residues of barley $(57 \%)$ and wheat $(53 \%)$. Mastitis $(66 \%)$, blackleg $(18 \%)$ and foot and mouth disease $(10 \%)$ were the most common dairy cattle health problems. On average, 1,977 Ethiopian birr was estimated for milk disposed from infected udders and cost of medication against various animal diseases per household/year. Artificial insemination and natural mating using genetically improved bulls were the two breeding methods for dairy animals. The average charges of artificial insemination and bull services were estimated to be 29 and 81 birr, respectively. The average milk yield per cow was 10 liters/day. Milking was dominantly done by housewives twice a day. Average calving interval (14 months), age at first calving ( 31 months), and lactation length (9.4 months) was reported for crossbred cows. The major dairy production constraints identified in this study were shortage of feed, poor nutritional quality, high veterinary cost and shortage of veterinary clinics and veterinarians. Thus it is recommended that there is a need to conserve feed, introduce improved forage species and improve animal health services, which will enhance the productivity and profitability of the dairy sector in the study areas.
\end{abstract}

Key words: Dairy production, feed, health, reproduction

\section{INTRODUCTION}

Ethiopia has the largest cattle population in Africa, estimated at 53.4 million, including 11.4 million milking cows that, in 2012, produced 3.5 billion liters of milk worth $\$ 1.2$ billion which are mainly kept by smallholder farmers (CSA, 2012). Cattle also provide traction power, produce meat and manure, and serve as insurance or emergency currency in times of drought or household crisis. The country has a favorable climate for keeping high yielding dairy breeds, which has huge potential for feed production as well as an ever increasing demand for

*Corresponding author. E-mail: ababfereja@gmail.com.

Author(s) agree that this article remain permanently open access under the terms of the Creative Commons Attribution License 4.0 International License 
milk and milk products (Mohammed et al., 2004). Since, the dairy sector is not yet developed to the expected level and its contribution to the national economy is fairly low

In Ethiopia, milk and milk products play an important role in household food security and income for smallholder farmers. Tefera (2010) argued that in the central Ethiopia, households owning larger livestock herds are less affected by food insecurity. The vast majority of smallholder farmers in the Ethiopia use low input production systems that relates to relatively low milk yield per cow/day (Zelalem et al., 2011). In these systems, animals are fed on crop residues and roadside grass, which are relatively low in protein and digestibility (Yoseph et al., 2003) and rarely supplemented with small quantities of agro industrial by products (Ahmed et al., 2010). As a result, productivity is low, animals reach puberty at a late age (often older than 24 months) and calving interval is long (often 18 to 24 months) (Ibrahim et al., 2011).

Herd management practices in nutrition and housing play major roles in predisposing individual animals to diseases (Wanapat and Chanthakhoun, 2011; Juyal et al., 2011). MoA and ILRI (2013) also reported that healthrelated problems seem to be one of the greatest problems faced by Ethiopian dairy farmers. Hence, improving the herd management systems combined with sustainable veterinary services is critical to optimize production and profitability of the smallholder farmers. With increased demands of dairy products and human population, the continuing importance of the dairy sector in the Ethiopian economy depends on increased productivity through good management practices. To bring this into effect, it is essential to understand the existing dairy production systems to make improvement interventions to the smallholder dairy production system as it is the dominant type of dairy production system in the country.

\section{MATERIALS AND METHODS}

\section{The study areas}

The study was conducted in eight selected dairy potential areas in the Ethiopian central highlands. Except for Debre Berhan, which is located in the Amhara region, the remaining seven areas, namely; Sheno, Sendafa, Chancho, Fiche, Degem, Debre Zeit and Asella are situated in the Oromia regional state. All the eight target dairy potential areas are located within a radius of $175 \mathrm{~km}$ from Addis Ababa. The average minimum and maximum temperatures of the areas range from the lowest 2.4 and $23.3^{\circ} \mathrm{C}$ at Debre Berhan to the highest 8 and $28^{\circ} \mathrm{C}$ at Debre Zeit, respectively. The areas are located within altitudes that range from the lowest $1600 \mathrm{~m}$ at Debre Zeit to the highest 3000 meter at Fiche, while receiving an annual rainfall that range from the minimum $860 \mathrm{~mm}$ for Debre Zeit to the maximum $1200 \mathrm{~mm}$ for Fiche.

\section{Data collection and sampling}

A semi-structured questionnaire was used to solicit information on socio economic characteristics of dairy production with the major areas being: Household characteristics, herd structure, dairy management practices such as animal feed, breeding and housing practice, record keeping, animal health and related constraints; as well as productive and reproductive performance of cows. From each study sites four representative Kebeles were randomly selected. Based on their willingness to provide information, a total of 320 (40 from each of the aforementioned 8 dairy potential areas) that own at least one milking cow were selected and interviewed.

\section{Data analysis}

The collected data were analyzed using appropriate quantitative and qualitative statistical procedures of SPSS version 16. Descriptive statistical namely mean and percentage; and standard error were used for the data analysis.

\section{RESULTS AND DISCUSSION}

\section{Socio-economic characteristics of households}

The age of the respondent household $(\mathrm{HH})$ heads averaged at 42, and on average, holding 1.2 ha of land per $\mathrm{HH}$ (Table 1). Similar land holding was reported for other areas such as 1.14 ha in Shashemene - Dilla areas (Sintayehu et al., 2008). Higher land holdings of 2.6 ha reported for Bahir Dar Zuria and Ginchi areas (Getachew, 2002; Asaminew and Eyassu, 2009). Though, land is one of the important pre-requisites for any farming activity, the average land holding/ $\mathrm{HH}$ (1.2 ha) reported in the current study is lower than the national average value (1.60 ha) reported by FAO (2008). This shows small land holding to be one of the major challenges for dairy producers in current study areas, which is also the case in a number of other parts of the country. To make matters worse, the land size owned is diminishing due to competition for alternative uses such as for crop cultivation and construction works relating to the increasing human population as well as urbanization.

The highest educational level achieved by $\mathrm{HH}$ heads was first degree $(6.58 \%)$, followed by diploma (12\%) with the remaining sample respondents having educational backgrounds between secondary and primary school education (Table 1). A minimum of preferably a higher educational level when achieved by farmers apparently facilitates not only a better understanding but also a higher adoption of new technologies/innovations. As confirmed by Lemma et al. (2012), for instance, farmers who have better level of education adopted improved dairy husbandry practices faster than those with low educational level. Other studies such as Gizaw et al. (2012), also revealed the apparent contribution of higher level of education to better husbandry practices.

The overall mean family size reported in study areas was 4.4 persons per $\mathrm{HH}$ (Table 1), which is lower than the national average (5.2), as reported by CACC (2003). Larger family sizes of 7.4 and 6 were, however, reported for Shashemene - Dilla (Sintayehu et al., 2008) and 
Table 1. Socio economic characteristics of $\mathrm{HHs}(\mathrm{N}=320)$.

\begin{tabular}{|c|c|c|c|c|c|c|c|c|c|}
\hline \multirow{2}{*}{ Variable } & \multicolumn{8}{|c|}{ Study sites } & \multirow{2}{*}{$\begin{array}{c}\text { Overall } \\
\text { mean }\end{array}$} \\
\hline & 1 & 2 & 3 & 4 & 5 & 6 & 7 & 8 & \\
\hline Age (year) & $53(1.6)$ & $48.6(1.6)$ & $37(1.6)$ & $40.35(2.1)$ & $38.5(3.6)$ & $39.5(1.9)$ & $41.8(1.7)$ & $41.9(1.7)$ & $42.4(0.6)$ \\
\hline Land holding (ha) & $0.7(0.2)$ & $0.4(0.1)$ & $2.18(0.1)$ & $0.14(0.02)$ & $1.3(0.1)$ & $1.75(0.2)$ & $0.18(0.02)$ & $1.9(0.2)$ & $1.2(0.06)$ \\
\hline \multicolumn{10}{|c|}{ Educational status (\%) } \\
\hline First degree & 10.0 & 11.2 & 0.0 & 15.0 & 12.0 & 0.0 & 4.5 & 0.0 & 6.58 \\
\hline Diploma & 10.0 & 27.5 & 0.0 & 20.0 & 30.0 & 10.0 & 1.2 & 0.0 & 12.33 \\
\hline Secondary & 30.0 & 37.0 & 15.0 & 44.8 & 18.0 & 0.0 & 62.0 & 37.5 & 30.54 \\
\hline Primary & 45.0 & 24.3 & 67.5 & 15.2 & 40.0 & 90.0 & 32.3 & 62.5 & 47.1 \\
\hline Illiterate & 5.0 & 0.0 & 17.5 & 5.0 & 0.0 & 0.0 & 0.0 & 0.0 & 3.43 \\
\hline \multicolumn{10}{|l|}{ Religions (\%) } \\
\hline Orthodox & 100 & 82.5 & 100 & 100 & 100 & 100 & 70.0 & 85.0 & 92.5 \\
\hline Muslim & 0.0 & 0.0 & 0.0 & 0.0 & 0.0 & 0.0 & 12.5 & 7.5 & 2.5 \\
\hline Protestant & 0.0 & 17.4 & 0.0 & 0.0 & 0.0 & 0.0 & 17.5 & 7.5 & 5.3 \\
\hline Family size & $5.7(0.3)$ & $4.0(0.4)$ & $3.8(0.3)$ & $4.8(0.4)$ & $4.9(0.2)$ & $3.3(0.2)$ & $4.6(0.3)$ & $4.4(0.3)$ & $4.4(0.1)$ \\
\hline
\end{tabular}

1=DebreBerhan, 2=Sheno, 3=Sendafa, 4=Chancho, 5=Fiche, 6=Degem, 7=Debrezeit, 8=Asella; numbers in the bracket indicates the standard error of means.

Table 2. Average (SE) cattle herd size and composition ( $N=320)$.

\begin{tabular}{|c|c|c|c|c|c|c|c|c|c|}
\hline \multirow{2}{*}{ Cattle type } & \multicolumn{8}{|c|}{ Study sites } & \multirow{2}{*}{$\begin{array}{c}\text { Overall } \\
\text { mean }\end{array}$} \\
\hline & 1 & 2 & 3 & 4 & 5 & 6 & 7 & 8 & \\
\hline Milking cow ${ }^{a}$ & $2.3(0.26)$ & $2.27(0.22)$ & $4.4(0.3)$ & $3.9(0.5)$ & $1.5(0.6)$ & $2.7(0.2)$ & $1.4(0.2)$ & $1.2(0.1)$ & $2.5(0.1)$ \\
\hline Dry cow ${ }^{a}$ & $0.85(0.25)$ & $0.52(0.12)$ & $0.5(0.08)$ & $1.2(0.0)$ & $0.2(0.06)$ & $0.1(0.1)$ & $0.2(0.1)$ & $0.33(0.7)$ & $0.5(0.3)$ \\
\hline Heifers $^{a}$ & $0.95(0.24)$ & $0.67(0.9)$ & $2.45(0.17)$ & $1.2(0.2)$ & $0.8(0.7)$ & 0.0 & $0.7(0.6)$ & $0.37(0.1)$ & $0.9(0.1)$ \\
\hline Calves $^{a}$ & $0.05(0.03)$ & $0.3(0.9)$ & 0.0 & 0.0 & 0.0 & $0.1(0.1)$ & $0.2(0.1)$ & $0.3(0.04)$ & $0.1(0.02)$ \\
\hline Bull $^{\mathrm{a}}$ & $0.05(0.03)$ & $0.05(0.03)$ & $0.35(0.1)$ & $0.42(0.1)$ & $0.1(0.04)$ & 0.0 & $0.1(0.1)$ & $1.0(0.2)$ & $0.3(0.1)$ \\
\hline Oxen $^{\mathrm{a}}$ & $0.9(0.2)$ & $0.05(0.03)$ & $1.5(0.26)$ & 0.0 & $0.1(0.4)$ & 0.0 & $0.15(0.1)$ & $1.1(0.14)$ & $0.5(0.1)$ \\
\hline Ave. Crossbred & $5.1(0.6)$ & $3.9(0.3)$ & $9.2(0.17)$ & $6.7(0.7)$ & $2.7(0.2)$ & $2.9(0.2)$ & $2.6(0.3)$ & $4.2(0.4)$ & $4.7(0.2)$ \\
\hline Ave. local cattle & $0.05(0.03)$ & $1.1(0.2)$ & $0.5(0.08)$ & 0.0 & 0.0 & $0.4(0.1)$ & $0.3(0.1)$ & $2.1(0.2)$ & $0.5(0.1)$ \\
\hline Overall Av. Cattle & $5.15(0.6)$ & $5(0.4)$ & $9.7(0.2)$ & $6.7(0.7)$ & $2.7(0.2)$ & $3.3(0.2)$ & $3(0.2)$ & $6.4(0.4)$ & $5.2(0.2)$ \\
\hline
\end{tabular}

a =crossbreds; 1=Debre Berhan, 2=Sheno, 3=Sendafa, 4=Chancho, 5=Fiche, 6=Degem, 7=Debre Zeit, 8=Asella.

Jimma (Belay et al., 2011) areas, respectively. Family size and age are indicative of household working age groups and family labour situations. The larger family size in Debre Berhan compared to other study sites implies that these HHs have good sources of family labor to utilize for different routine dairy farm activities such as feeding, herding, cleaning, and milking and milk processing. The majority of the respondents (92.2\%) are members of Ethiopian Orthodox Tewahido church and the rest are Muslims and Protestants.

\section{Cattle Herd Structure}

The mean cattle holding per $\mathrm{HH}$ were 5.2 heads (Table 2), which is much lower than $\mathrm{HH}$ cattle holding (8) reported by Negussie (2006) in Mekele area. The difference in cattle holding per $\mathrm{HH}$ might be associated with the availability of land for grazing and feed production. The overall mean numbers of crossbred milking cows, dry cows, heifers, calves, bulls and oxen per $\mathrm{HH}$ were $2.5,0.5,0.9,0.1,0.3$, and 0.5 , respectively (Table 2). The average crossbred dairy herd per $\mathrm{HH}$ was 4.7 heads which is closer to 4.3 reported in the west Shewa zone of Oromia (Derese, 2008). Higher numbers of crossbred cows/HH were reported (5.4-11) in Sebeta, Bahir Dar and Hawassa (Yitaye, 2008; Haile et al., 2012; Dereje and Yoseph, 2014). In this study, the dairy farmers own higher numbers of crossbred dairy cows than local breed ones. This might be because of availability of promising markets for dairy products and better access to farm inputs such as improved genotype 
Table 3. Source of incomes and farmers involved in dairy cooperatives in the study areas $(\mathrm{N}=320)$.

\begin{tabular}{lccccccccc}
\hline Variable (\%) & \multicolumn{7}{c}{ Study sites } & \multicolumn{1}{c}{$\begin{array}{c}\text { Overall } \\
\text { mean }\end{array}$} \\
\cline { 2 - 9 } & 1 & 2 & 3 & 4 & 5 & 6 & 7 & 8 & \\
Sources of income & & & & & & & & & \\
Dairy production & 44.5 & 26.3 & 61.1 & 49.8 & 43.5 & 38.0 & 54.0 & 44.6 & 43.6 \\
Crop production & 19.4 & 19.1 & 25.4 & 0.0 & 12.0 & 35.0 & 0.0 & 19.6 & 18.0 \\
Trade & 3.0 & 17.7 & 8.7 & 5.7 & 8.0 & 10.0 & 19.3 & 8.2 & 10.1 \\
Public organization employment & 15.5 & 23.4 & 0.0 & 20.6 & 12.5 & 8.0 & 10.3 & 4.8 & 11.8 \\
Private company employment & 2.0 & 6.0 & 0.0 & 21.1 & 6.5 & 0.0 & 16.2 & 0.7 & 6.5 \\
Other sources & 15.6 & 7.5 & 4.7 & 2.6 & 17.5 & 9.0 & 0.0 & 22.0 & 9.7 \\
Member of cooperatives & 40.0 & 60.0 & 0.0 & 0.0 & 30.0 & 0.0 & 72.5 & 65.0 & 33.4 \\
Source of information & & & & & & & & & \\
Members & 49.6 & 79.2 & - & - & 33.3 & - & 89.7 & 76.9 & 65.75 \\
Cooperatives office & 50.4 & 20.8 & - & - & 66.7 & - & 10.3 & 23.1 & 34.25 \\
Reasons for motivation & & & & & & & & & \\
Regular milk market & 37.5 & 75.0 & - & - & 0.0 & - & 100 & 52.2 & 52.9 \\
Access inputs and regular milk market & 62.5 & 25.0 & - & - & 100 & - & 0.0 & 47.8 & 47.0 \\
\hline
\end{tabular}

1=Debre Berhan, 2=Sheno, 3=Sendafa, 4=Chancho, 5=Fiche, 6=Degem, 7=Debre Zeit, 8=Asella; other refers daily labour, livestock other than dairy, pension and support from sons and daughters.

and commercial feeds in the study areas.

Milking cows comprised a larger percentage of the dairy herd in the study areas, which shows that crossbred milking cows are playing a significant role in the economy of dairy producers. However, lower numbers of milking cows $(0.1-1.7$ per $\mathrm{HH})$ reported in different parts of the country (Lemma, 2004; Binyam, 2008; Samson et al., 2012). Few numbers of improved bulls used for natural mating were reported in the study areas. The highest average $\mathrm{HH}$ holding of replacement heifers was reported from Sendafa (2.45) followed by Chancho (1.2) and Debre Berhan (0.95). The average number of calves estimated was lower compared with other groups of cattle probably because male calves are traditionally viewed as an un-wanted product of the dairy sector. As a result many of the dairy farmers in the study cull male calves at a very early age to reduce rearing cost.

\section{Major income sources and farmers involved in the dairy cooperatives}

Dairy cattle owners of the sampled respondents generate income from different sources, however, for the majority of them dairying was the main source of income at varying scale. As observed from the present assessment, the contribution of dairying to the total household income was ranged from $21-61 \%$ (Table 3 ). Similar studies conducted on smallholder farmers in southern Ethiopia indicated that dairying on average contributed about 20$50 \%$ to the total income of the farmers (Asrat et al., 2013; Abebe et al., 2014). The discrepancies in contribution of dairying to the total income of the farmers from place to place are due to differences in cattle herd size, income from other sources, land size, productivity of cow and milk market outlets (Sintayehu et al., 2008; Asrat et al., 2013).

Only $33.4 \%$ of the sampled dairy farmers found to be a member of dairy cooperative (Table 3). However, the majority of sampled HHs (60-72.5\%) in Asella, Debre Zeit and Sheno were members of a dairy cooperative. Dairy farmers who are members of the cooperatives are benefited from easy access to milk market and/or farm input supplies, which would otherwise be difficult at individual farmer level. In this regard, 52.9 and $47 \%$ of the sampled dairy farmers in study area were motivated to join dairy cooperatives due to the regular fresh milk market, and supply of farm inputs and availability of regular milk market, respectively. The sampled dairy producers across the study sites got information about the cooperatives from previous members $(66 \%)$ and cooperative offices (34\%) prior to joining. In contrast, none of the surveyed dairy producers in Sendafa, Chancho and Degem were members of the dairy cooperatives. This could be due to the existence of alternative milk market outlets, regular fluctuation of the milk price, and insufficient farm input supplies of the dairy cooperatives.

\section{Dairy cattle management}

\section{Dairy cattle feeds}

Although grazing land used as a feed source is varying across the study sites, $60 \%$ of the surveyed farmers 
Table 4. Major feed resources available for dairy animals $(\mathrm{N}=320)$.

\begin{tabular}{|c|c|c|c|c|c|c|c|c|c|}
\hline \multirow{2}{*}{ Parameter (\%) } & \multicolumn{8}{|c|}{ Study sites } & \multirow{2}{*}{$\begin{array}{c}\text { Overal } \\
\text { mean }\end{array}$} \\
\hline & 1 & 2 & 3 & 4 & 5 & 6 & 7 & 8 & \\
\hline Grazing & 45.0 & 54.0 & 92.0 & 10.2 & 100 & 85.5 & 7.8 & 100 & 61.8 \\
\hline \multicolumn{10}{|l|}{ Crop residues } \\
\hline Barely & 48.3 & 57.7 & 75.0 & 50.0 & 95.0 & 77.7 & 0.0 & 52.6 & 57.1 \\
\hline Wheat & 48.2 & 47.8 & 35.0 & 50.0 & 50.0 & 49.96 & 95.9 & 45.8 & 52.8 \\
\hline Teff & 0.0 & 0.0 & 35.0 & 0.0 & 100 & 0.0 & 50.0 & 0.0 & 23.1 \\
\hline Faba bean & 46.7 & 20.0 & 67.1 & 0.0 & 0.0 & 0.0 & 0.0 & 10.0 & 17.9 \\
\hline Grass hay & 95.1 & 90.5 & 100 & 100 & 88.0 & 100 & 91.0 & 87.5 & 94.0 \\
\hline \multicolumn{10}{|l|}{ Constraints } \\
\hline Shortage of feed & 36.0 & 30.0 & 23.0 & 40.0 & 30.0 & 18.0 & 45.0 & 35.0 & 32.4 \\
\hline Poor quality & 20.0 & 15.0 & 28.0 & 27.0 & 25.0 & 19.0 & 18.0 & 26.0 & 22.3 \\
\hline High feed cost & 23.0 & 20.0 & 25.0 & 25.0 & 15.0 & 20.0 & 32.4 & 5.0 & 20.7 \\
\hline
\end{tabular}

1=Debre Berhan, 2=Sheno, 3=Sendafa, 4=Chancho, 5=Fiche, 6=Degem, 7=Debre Zeit, 8=Asella.

reported to use natural pasture as a major source of feed. However, the majority of dairy farmers in Chancho and Debre Zeit had less access to grazing lands for their dairy animals, which might be due to the increasing expansion of urbanization in the areas (Table 4). In contrast, 54$100 \%$ of the respondents in Sheno, Sendafa, Fiche, Degem and Asella, depend on grazing land to feed their dairy animals. In Ethiopia, it is estimated that natural pasture provides about $80-90 \%$ of the total livestock feed intake with decreasing trends (Alemayehu, 2003). As stated by same author, however, grazing on natural pasture is neither quantitatively nor qualitatively adequate to support profitable dairy production.

Crop residues are the second most important source of livestock feed next to natural pastures in Ethiopia (Berhanu et al., 2009; FAO, 2011) and provides 10 to $15 \%$ of the total livestock feed intake (Alemayehu, 2003). Wheat, barley, teff and Faba bean residues reported to be the major crop residues available for dairy animals in study areas. The availability of crop residues were differs across the study areas. For example, teff straw being only available in Fiche and Debre Zeit while the use of Faba bean straw as feed source for dairy animals was reported by larger proportions of $\mathrm{HH}$ in Debre Berhan, Sheno and Sendafa. The majority of the respondents (94\%) also reported grass hay as a common feed source for dairy animals. Previous reports by Yoseph et al. (2003), in urban and peri-urban dairy farmers around Addis Ababa milk-shed and Sintayehu et al. (2008) in Shashemene - Dilla areas showed that hay is the most common feed resource available for dairy animals.

To alleviate feed shortage, dairy producers across the study sites purchased feeds from markets and/or other famers from the surrounding areas. Among the roughage feedstuffs, grass hay and crop residues of teff, wheat and barley were the major types of feed purchased by producers. Grass hay is usually sold in baled form while crop residues are in a loose form and transported in variety of means: Such as human backs, carts and trucks. According to the respondents, lactating cows were supplemented with small quantities of concentrate feed ingredients of agro-industrial by-products. Feed shortage, high feed cost as well as poor nutritional quality of available feeds were the major constraints of dairy production in the study areas (Table 4). According to the response of $32 \%$ of the sampled $\mathrm{HHs}$, feed shortage is the main constraint for dairy cattle production, while the rest about 22 and $20 \%$ of them indicated that quality and cost of the feeds, respectively, are the important constraints for dairy production. This is in line with Adugna et al. (2012) and Fekede et al. (2014), who reported that shortages of feed supply, high feed cost and poor nutritional quality of the available feed resource, are the major constraints affecting livestock productivity in the central highlands of Ethiopia.

\section{Sources of water for dairy cattle}

The availability of water sources for dairy animals reported to vary across the study sites (Table 5). About half of the interviewed dairy farmers were dependent on tap water followed by river, spring and bore-well water. As noted from the study, the overall average distance to access spring and river watering points were 0.4 and 0.9 $\mathrm{km}$, respectively. As indicated in Table 5 the majority of the respondents had tap water at their homesteads and hence they would not necessarily trek their animals to distant areas. In Debre Berhan and Sheno, and Debre Zeit dairy farmers mostly provide water for dairy animals more than three times a day, whereas the rest provide twice a day.

The majority of the respondents $(50-91 \%)$ in Sendafa, 
Table 5. Source and watering frequency of water and constraints related to water $(N=320)$.

\begin{tabular}{|c|c|c|c|c|c|c|c|c|c|}
\hline \multirow{2}{*}{ Variable (\%) } & \multicolumn{8}{|c|}{ Study sites } & \multirow{2}{*}{$\begin{array}{c}\text { Overall } \\
\text { mean }\end{array}$} \\
\hline & 1 & 2 & 3 & 4 & 5 & 6 & 7 & 8 & \\
\hline \multicolumn{10}{|l|}{ Source of water } \\
\hline Tap & 65.0 & 67.0 & 0.0 & 75.0 & 80.0 & 0.0 & 100 & 10.0 & 49.6 \\
\hline River & 30.0 & 25.0 & 0.0 & 15.0 & 15.0 & 10.0 & 0.0 & 87.5 & 22.8 \\
\hline Spring & 5.0 & 8.0 & 0.0 & 10.0 & 5.0 & 90.0 & 0.0 & 2.5 & 15.1 \\
\hline Bore-well & 0.0 & 0.0 & 100 & 0.0 & 0.0 & 0.0 & 0.0 & 0.0 & 12.5 \\
\hline \multicolumn{10}{|c|}{ Watering frequency/day } \\
\hline Thrice and more & 65.0 & 62.1 & 0.0 & 20.0 & 12.5 & 15.0 & 60.0 & 10.0 & 30.6 \\
\hline Twice & 35.0 & 37.9 & 87.5 & 80.0 & 87.5 & 85.0 & 40.0 & 65.0 & 64.7 \\
\hline Once & 0.0 & 0.0 & 12.5 & 0.0 & 0.0 & 0.0 & 0.0 & 25.0 & 4.7 \\
\hline \multicolumn{10}{|l|}{ Constraints } \\
\hline Seasonality & 20.0 & 25.0 & 91.0 & 76.0 & 50.0 & 88.9 & 0.0 & 20.0 & 46.4 \\
\hline Poor quality & 5.0 & 2.5 & 9.0 & 24.0 & 10.0 & 11.1 & 0.0 & 80.0 & 17.7 \\
\hline Far watering point & 15.0 & 17.0 & 0.0 & 0.0 & 5.0 & 0.0 & 0.0 & 0.0 & 4.6 \\
\hline No problem & 60.0 & 55.5 & 0.0 & 0.0 & 35.0 & 0.0 & 100 & 0.0 & 31.3 \\
\hline
\end{tabular}

1=Debre Berhan, 2=Sheno, 3=Sendafa, 4=Chancho, 5=Fiche, 6=Degem, 7=Debre Zeit, 8=Asella.

Chancho, Fiche and Degem mentioned seasonality of water availability as a major constraint, but water quality problem was more (80\%) prominent in Asella. Water from rivers and springs are reported to dry up early during dry seasons, which made the problem of water availability even more critical in these areas. To solve this problem, farmers were digging wells and trekking to long distances to access water for the dairy animals. Trekking of dairy animals for a long distance has been reported to cause considerable energy wastage (Asfaw et al., 2010), and decrease watering frequency which in turn contributes to low dairy cow productivity (Kassahun et al., 2008).

\section{Dairy cattle health}

The majority of the respondents $(66.4 \%)$ encountered udder infection in their dairy herd (Table 6) with the highest rates in Sendafa, Chancho and Degem. Almost all the sampled $\mathrm{HHs}$ used veterinary medicines to treat sick animals, as opposite to a few famers (12.5-23\%) around Degem and Debre Zeit who used traditional medicines. Eighty percent of the respondents discarded the milk produced from infected udders, while the rest provided it to calves or dogs. The other most common dairy cattle disease reported in Debre Berhan and Degem were blackleg (55-60\%), while half of the $\mathrm{HHs}$ in Chancho reported both foot and mouth disease (FMD) and lumpy skin disease (LSD). Several earlier studies carried out in different parts of Ethiopia reported that anthrax, FMD, mastitis, pasteurollosis, blackleg and LSD were the leading dairy cattle health problems (Tesfahiwot, 2004; Kuastros, 2007; Gebremedhin, 2007;
Azage et al., 2013).

Health of the dairy cows has a great impact on farm profit. As evidenced from the study, the average estimated value of milk disposed per $\mathrm{HH} /$ year was 1,146 ETB due to udder infection. This indicates that mastitis is one of the major diseases that cause high economic loss. Moreover, the estimated average cost of medication to treat animals against different diseases was 831 birr per $\mathrm{HH} /$ year. According to the respondents, about $46.7 \%$ of the HHs had limited access to veterinary services due to high veterinary cost, and shortage of veterinary clinics and veterinarians.

\section{Breeding practices}

It is observed that dairy farmers practiced two breeding methods:natural mating (using genetically improved bulls) and artificial insemination (Al) or a combination of the two methods depending on availability. Forty percent of the $\mathrm{HH}$ s solely used $\mathrm{Al}$ for breeding the dairy animals, those who used the combination of $\mathrm{Al}$ and improved bulls constituted about $53 \%$ (Table 7). Because of government subsidies, farmers are charged only 4 birr per Al service in Ethiopia. However, the actual cost of Al service obtained from Debre Berhan (50 birr), Chanacho (83 birr) and Debre Zeit (53 birr) were extremely expensive. This might be due to the fact that the service is mostly provided by private Al technicians.

The use of bulls for natural service is common in Ethiopia, and considered as the best solution in areas where Al service is inadequate and unavailable (MOARD, 2007). The majority of the respondents (89.3\%) used 
Table 6. Major dairy cattle diseases and treatment methods $(\mathrm{N}=320)$.

\begin{tabular}{|c|c|c|c|c|c|c|c|c|c|}
\hline \multirow{2}{*}{ Parameter (\%) } & \multicolumn{8}{|c|}{ Study sites } & \multirow{2}{*}{$\begin{array}{c}\text { Overal } \\
\text { mean }\end{array}$} \\
\hline & 1 & 2 & 3 & 4 & 5 & 6 & 7 & 8 & \\
\hline \multicolumn{10}{|l|}{ Major diseases } \\
\hline Mastitis & 55.0 & 65.0 & 82.5 & 85.0 & 53.0 & 90.0 & 45.5 & 55.5 & 66.4 \\
\hline Blackleg & 55.0 & 0.0 & 0.0 & 0.0 & 10.0 & 60.0 & 0.0 & 20.0 & 18.1 \\
\hline FMD & 0.0 & 7.5 & 10.0 & 50.0 & 0.0 & 10.0 & 0.0 & 0.0 & 9.68 \\
\hline LSD & 0.0 & 0.0 & 15.0 & 50.0 & 0.0 & 0.0 & 0.0 & 0.0 & 8.1 \\
\hline In. parasite & 15.0 & 7.5 & 0.0 & 0.0 & 0.0 & 0.0 & 0.0 & 0.0 & 2.8 \\
\hline Anthrax & 0.0 & 0.0 & 0.0 & 0.0 & 0.0 & 20.0 & 0.0 & 0.0 & 2.5 \\
\hline Pasteurollosis & 0.0 & 0.0 & 0.0 & 10.5 & 0.0 & 0.0 & 0.0 & 0.0 & 1.31 \\
\hline \multicolumn{10}{|c|}{ Milk from infected udder } \\
\hline Disposed & 100 & 88.5 & 100 & 62.7 & 100 & 50.0 & 53.8 & 85.0 & 80.0 \\
\hline For calves & 0.0 & 0.0 & 0.0 & 37.3 & 0.0 & 50.0 & 23.1 & 0.0 & 13.8 \\
\hline For dog & 0.0 & 11.5 & 0.0 & 0.0 & 0.0 & 0.0 & 23.1 & 15.0 & 6.2 \\
\hline \multicolumn{10}{|c|}{ Methods of treatment } \\
\hline Veterinary & 100 & 100 & 100 & 100 & 100 & 87.5 & 76.9 & 100 & 96.0 \\
\hline Traditional & 0.0 & 0.0 & 0.0 & 0.0 & 0.0 & 12.5 & 23.1 & 0.0 & 4.0 \\
\hline
\end{tabular}

1=DebreBerhan, 2=Sheno, 3=Sendafa, 4=Chancho, 5=Fiche, 6=Degem, 7= DebreZeit, 8=Asella; FMD=Foot and Mouth Disease, LSD=Lumpy Skin Disease

Table 7. Breeding method, source of semen and service charge $(\mathrm{N}=320)$.

\begin{tabular}{|c|c|c|c|c|c|c|c|c|c|}
\hline \multirow{2}{*}{ Variable } & \multicolumn{8}{|c|}{ Study sites } & \multirow{2}{*}{$\begin{array}{c}\text { Overall } \\
\text { mean }\end{array}$} \\
\hline & 1 & 2 & 3 & 4 & 5 & 6 & 7 & 8 & \\
\hline \multicolumn{10}{|l|}{ Breeding methods (\%) } \\
\hline $\mathrm{Al}$ & 35.0 & 17.5 & 17.5 & 70.0 & 40.0 & 20.0 & 82.5 & 35.0 & 39.7 \\
\hline Natural mating & 25.0 & 7.5 & 0.0 & 0.0 & 0.0 & 10.0 & 0.0 & 15.0 & 7.2 \\
\hline Both & 40.0 & 75.0 & 82.5 & 30.0 & 60.0 & 70.0 & 17.5 & 50.0 & 53.1 \\
\hline \multicolumn{10}{|l|}{ Source of bull (\%) } \\
\hline Neighbor & 84.6 & 100 & 77.6 & 80.0 & 83.3 & 100 & 100 & 88.5 & 89.3 \\
\hline Own & 15.4 & 0.0 & 22.4 & 20.0 & 16.7 & 0.0 & 0.0 & 11.5 & 9.7 \\
\hline \multicolumn{10}{|c|}{ Price/service mean (SE) } \\
\hline Al & $50(3.8)$ & $4(3.6)$ & $12(3.3)$ & 83(3.3) & $12.0(3.8)$ & $6.0(3.5)$ & $53.0(3.3)$ & $18.0(3.8)$ & $29.8(1.2)$ \\
\hline Bull & $79.3(5)$ & $73.3(4.4)$ & - & $133.0(7.6)$ & $77.5(4.6)$ & $60.0(3.5)$ & $80.0(9.3)$ & $65.0(7.6)$ & $81.2(2.4)$ \\
\hline Record keeping (\%) & 10.0 & 5.4 & 6.31 & 75.0 & 10.0 & 60.0 & 22.5 & 7.5 & 24.0 \\
\hline
\end{tabular}

1=Debre Berhan, 2=Sheno, 3=Sendafa, 4=Chancho, 5=Fiche, 6=Degem, 7= Debre Zeit, 8=Asella; SE= standard eror of mean, Al= Artifical Insemination.

breeding bulls not reared in their herd, while only about $14 \%$ of them used homebred bulls. The average bull service charge was estimated to be 81 ETB/service, which is expensive when compared to Al service. However, bull service charge was not common in Sendafa which might be associated with cultural taboo in the area.

Record keeping is the basis for proper livestock husbandry. As indicated by Markos (2006), livestock development in Ethiopia has been handicapped to a great extent due to lack of recorded data. The study found that farmers do not keep the necessary farm records pertaining to their dairy animals. However, $24 \%$ of the sampled dairy herd owners to some extent tried to keep records on breeding dates until the animals gives calves, and daily milk sales for about 15-30 days using informal sheet. It is therefore essential to provide training on this useful practice to dairy herd owners to make decision for better livestock management, and thereby optimize the utilization of the available resources in the study areas. 
Table 8. Dairy animal housing practices in the study areas $(\mathrm{N}=320)$.

\begin{tabular}{|c|c|c|c|c|c|c|c|c|c|}
\hline \multirow{2}{*}{ Variable (\%) } & \multicolumn{8}{|c|}{ Study sites } & \multirow{2}{*}{$\begin{array}{l}\text { Overal } \\
\text { mean }\end{array}$} \\
\hline & 1 & 2 & 3 & 4 & 5 & 6 & 7 & 8 & \\
\hline \multicolumn{10}{|l|}{ Roof type } \\
\hline Corrugated & 90.0 & 85.0 & 100 & 100 & 90.0 & 80.0 & 92.5 & 45.0 & 85.3 \\
\hline Thatched & 10.0 & 15.0 & 0.0 & 0.0 & 10.0 & 20.0 & 7.5 & 55.0 & 14.7 \\
\hline \multicolumn{10}{|l|}{ Floor type } \\
\hline Cement & 18.5 & 72.5 & 82.5 & 87.5 & 40.0 & 30.0 & 45.0 & 25.6 & 50.2 \\
\hline Stone & 70.0 & 20.0 & 17.5 & 7.5 & 33.0 & 49.0 & 23.0 & 51.0 & 33.9 \\
\hline Earthen & 11.5 & 7.5 & 0.0 & 5.0 & 27.0 & 21.0 & 32.0 & 23.4 & 15.9 \\
\hline Bedding used & 0.0 & 15.0 & 17.5 & 10.0 & 0.0 & 0.0 & 7.5 & 15 & 8.1 \\
\hline \multicolumn{10}{|c|}{ Cleaning frequency } \\
\hline Daily & 100 & 87.5 & 100 & 100 & 80.0 & 100 & 92.5 & 100 & 95.0 \\
\hline Twice/week & 0.0 & 5.0 & 0.0 & 0.0 & 10.0 & 0.0 & 0.0 & 0.0 & 1.8 \\
\hline Thrice/week & 0.0 & 7.5 & 0.0 & 0.0 & 10.0 & 0.0 & 7.5 & 0.0 & 3.12 \\
\hline
\end{tabular}

1=Debre Berhan, 2=Sheno, 3=Sendafa, 4=Chancho, 5=Fiche, 6=Degem, 7= Debre Zeit, 8=Asella.

\section{Dairy cattle housing}

Animal housing is important to protect animals from predators, theft, unfavorable weather conditions and for ease of undertaking husbandry practices (Sintayehu et al., 2008; Asrat et al., 2013). All sampled dairy herd owners across the study areas housed their animals in separate barns constructed purposefully for dairy cattle. This has advantage to limit the spread of diseases from animals to humans and vice versa. Similar results were reported by Solomon (2010) who indicated that $95.7 \%$ of the sample HHs in Arsi zone used separate housing for dairy cows. Asrat et al. (2013), however, reported that $83 \%$ of the total respondents in Wolayta zone kept their animals in the same house where the family lives.

The majority of the respondents (85\%) constructed dairy cattle barns with corrugated iron roofing material for better durability, while the rest (mainly from Asella) constructed with thatched grass (Table 8 ). The materials used to make the floor of the barns varied across the study areas. For instance, $72.5-87.5 \%$ of the sample HHs in Sheno, Sendafa and Chancho reported using cement flooring. While in Degem, Asella and Debre Berhan, 49$70 \%$ of the respondents used stone for flooring. Clean, dry and comfortable bedding material is important to minimize the growth of microorganisms. However, only $8 \%$ of the respondents reported to use bedding material (straw) for the dairy animals. The majority of the surveyed $\mathrm{HHs}(95 \%)$ cleaned the barn daily. Housing conditions in many of HHs were unclean, wet and not providing a comfortable setting for the dairy animals. This may have a negative impact on production of clean milk and milk products, in addition to increasing animal health problems. Therefore, cow sheds must be designed in such a way that it gives comfort for the animals, and easy for routine daily activities like cleaning and feeding.

\section{Milking, productive and reproductive performance of dairy cows}

As reported by the respondents, cows were milked by hand twice a day (morning and evening). Similarly Azage et al. (2013) reported that hand milking in Ethiopia is the sole milking method and milking frequency was twice a day. Milking was done dominantly by housewives $(65.9 \%)$ followed by husbands $(37 \%)$, hired labours $(29.7 \%)$ and sons (10.6\%) (Table 9). Milking in different parts of Ethiopia is primary handled by women, however, in a few areas such as the Fogera area of Amhara region, milking is entirely performed by males (Belete, 2006).

The mean age at first calving (AFC) reported for crossbred heifers were 31 months (ranges from 28.9 to 37 months). AFC in the present study was shorter than 47 months for crossbred cattle Amhara region as reported by Solomon et al. (2009). Age at first calving have an impact on the productive life span of the cows and rearing cost of the dairy animals (Ruiz-Sanchez et al., 2007).

The better-managed and well-fed heifers grew faster, served earlier and resulted in more milk and calves produced during their lifetime as well as low rearing costs (Masama et al., 2003).

The average daily milk yield (DMY) and lactation length (LL) of crossbred cows were 10 liters and 9.4 months, respectively (Table 9 ). Lower average daily milk (6.5 liters) was recorded in Asella may be attributed to differences in exotic gene level of the crossbred animals and management. The average DMY estimated in the 
Table 9. Milking and productive and reproductive performance of crossbred cows $(\mathrm{N}=320)$.

\begin{tabular}{|c|c|c|c|c|c|c|c|c|c|}
\hline \multirow{2}{*}{ Parameter } & \multicolumn{8}{|c|}{ Study sites } & \multirow{2}{*}{$\begin{array}{c}\text { Overall } \\
\text { mean }\end{array}$} \\
\hline & 1 & 2 & 3 & 4 & 5 & 6 & 7 & 8 & \\
\hline \multicolumn{10}{|c|}{ Performance(SE) } \\
\hline DMY (liter) & $9.95(0.5)$ & $9.9(0.3)$ & $14.8(0.5)$ & $13.3(1.6)$ & $9.5(0.5)$ & $11(0.8)$ & $11(0.85)$ & $6.5(0.2)$ & $10(0.24)$ \\
\hline LL (month) & $9.4(0.17)$ & $9.5(0.14)$ & $9.2(0.17)$ & $8.6(0.24)$ & $9.6(0.29)$ & $9.2(0.12)$ & $8.8(0.17)$ & $11.0(0.6)$ & $9.4(0.1)$ \\
\hline $\mathrm{Cl}$ (month) & $14(0.34)$ & $13.2(0.2)$ & $14.0(0.3)$ & $16.7(1.02)$ & $12.75(0.1)$ & $12.9(0.09)$ & $13.8(0.33)$ & $17.8(0.5)$ & $14.2(0.15)$ \\
\hline SPC (number) & $1.8(0.1)$ & $1.7(0.05)$ & $1.8(0.5)$ & $2.0(0.12)$ & $1.2(0.4)$ & $1.6(0.04)$ & $1.5(0.06)$ & $1.5(0.04)$ & $1.6(0.02)$ \\
\hline AFC (month) & $31(0.39)$ & $29.5(0.4)$ & $30.2(0.7)$ & $29.9(0.12)$ & $37(0.88)$ & $30(0.31)$ & $28.9(0.36)$ & $32.4(0.7)$ & $31.1(0.29)$ \\
\hline \multicolumn{10}{|l|}{ Who milks (\%) } \\
\hline Housewife & 85.0 & 55.0 & 50.0 & 35.0 & 60.0 & 80.0 & 70.0 & 92.5 & 65.9 \\
\hline Husband & 70.0 & 15.0 & 99.0 & 7.5 & 60.0 & 0.0 & 22.5 & 22.5 & 37.1 \\
\hline Hired labor & 20.0 & 42.5 & 50.0 & 65.0 & 30.0 & 30.0 & 0.0 & 0.0 & 29.7 \\
\hline Son & 5.0 & 0.0 & 0.0 & 20.0 & 0.0 & 10.0 & 15.0 & 35.0 & 10.6 \\
\hline Daughter & 0.0 & 7.5 & 0.0 & 0.0 & 10.0 & 10.0 & 0.0 & 20.0 & 5.9 \\
\hline
\end{tabular}

1=DebreBerhan, 2=Sheno, 3=Sendafa, 4=Chancho, 5=Fiche, 6=Degem, 7= DebreZeit, 8=Asella; DMY= Daily Milk Yield, LL=Lactation Length, Cl= Calving Interval, SPC=Service per Conception, AFC=Age at First Caving.

current study was comparable with the reports of Solomon (2010) in Arsi zone and Belete (2006) in Amhara region, which was $9.4 \mathrm{~L}$. However, it was higher compared to the values reported for some other parts of the country (Addisu et al., 2012; Mulugeta and Belaynhe, 2013). The average lactation length (LL) reported in current study is nearly similar with the recommended standards for lactation length (10 months), which is usually reported from modern dairy farms (Lobago, 2007). This result is also similar with earlier studies conducted in Sululta and Welmera districts (Mustefa, 2012; Mulugata and Belaynhe, 2013).

The overall mean calving interval $(\mathrm{Cl})$ reported for crossbred cow was 14.2 months, which is close to the optimum values (12-13months) recommended for profitable dairy production (Gifawosen et al., 2003). The ideal calving interval would result in a significant increase in the financial returns from milk production and the lifetime productivity of cows. The average $\mathrm{Cl}$ observed in this study is in consent with the studies of Addisu et al. (2012) who reported 14 months for crossbred cows in Ethiopia. In contrary, longer averages of $\mathrm{Cl}$ (16-21 months) were reported in Ethiopian highlands (Shiferaw et al., 2003; Belay et al., 2012). Generally, the variation in the average values of $\mathrm{Cl}$ and $\mathrm{LL}$ among the studies conducted in the country could be attributed to the difference in management practices, which brings different responses within the same breed.

The overall estimated average number of service per conception (SPC) for crossbred cows was 1.6 (Table 9). The average number of SPC required in this study nearly matches with the recommended value (1.5) suggested by Radostits et al. (1994), and agreed with the results from central highlands and mid Rift valley of Ethiopia (Shiferaw et al., 2003; Yifat et al., 2009). However, a higher average
SPC (2.8) was reported in Harar milk-shed (Mohammed and deWaal, 2009). Feed shortage and poor reproductive management such as lack of proper heat detection and timely insemination might have the most plausible explanation for difference in the number of SPC recorded across the country (Kumar et al., 2014).

\section{Conclusion}

Crossbred dairy cattle are dominant in the present study areas as compared to local breeds; and as a result dairy production is the main source of income for smallholder farmers in the study areas. The major feed resource available for dairy animals were natural grazing land, grass hay and crop residues of teff, wheat and barley. Tap, river, spring and bore-well are reported to be the common sources of water for the dairy animals. The entire dairy herd owners constructed separate barns for their dairy animals regardless of the cow comforts. Al and improved dairy bulls (often shared from neighbors) were the common methods for cattle breeding in the study areas. The awareness of the dairy farmers about record keeping is limited; it is not more than keeping information on daily milk sold and breeding dates. Feed shortage, poor quality and high price, seasonal availability of water and limited access to veterinary service were reported to be the major constraints of dairy production in the study areas. Farmer losses about 1,977ETB/year/HH due to milk discarded from infected udder and medication of diseased animals. Therefore, the present study shows that there is a need to improve the dairy cattle management such as feeding, disease preventions as well as record keeping of all necessary farm information to maximize milk production. 


\section{CONFLICT OF INTERESTS}

\section{The authors have not declared any conflict of interests.}

\section{REFERENCES}

Abebe B, Zelalem Y, Ajebu N (2014). Dairy production system and constraints in Ezha districts of the Gurage zone, Southern Ethiopia. Glob. Vet. 12(2):181-186

Addisu B, Mesfin B, Kindu M, Duncan A (2012). Production aspects of intensification and milk market quality in Amhara region, Ethiopia. Livest. Res. Rural Dev. 24:9. Available at: http://www.Irrd.cipav.org.co/Irrd24/9/bite24154.htm

Adugna T, Alemu Y, Alemayehu M, Dawit A, Diriba G, Getnet A, Lemma G, Seyoum B, Yirdaw W (2012). Livestock Feed Resources in Ethiopia: Challenges, Opportunities and the Need for Transformation. National Feed Committee Report, Ethiopian Animal Feed Industry Association (EAFIA) 'and the Ministry of Agriculture and Rural Development (MoARD). Addis Ababa, Ethiopia.

Ahmed H, Abule E, Mohammed YK, Treydte AC (2010). Livestock feed resources utilization and management as influenced by altitude in the Central Highlands of Ethiopia. Livest. Res. Rural Dev. 22(12).Available at: http://lrrd.cipav.org.co//rrd22/12/hass22229.htm

Alemayehu M (2003). Country pasture/forage resources profiles: Ethiopia. FAO (Food and Agriculture Organization of the United Nations), Rome, Italy.

Asaminew T, Eyassu S (2009). Smallholder dairy production system and emergence of dairy cooperatives in Bahir Dar Zuria and Mecha districts, north western Ethiopia. World J. Dairy Food Sci. 4 (2):185192.

Asfaw N, Zelealem Y, Aynalem H, Emmanuelle G (2010). Improving smallholders' marketed supply and market access for dairy and dairy products in the Arsi zone. Food and Agriculture Organization of the United Nations, Sub-Regional Office for Eastern Africa (FAO/SFE), Addis Ababa, Ethiopia.

Asrat A, Zelalem Y, AjebuN (2013). Characterization of milk production systems in and around Boditti, South Ethiopia. Livest. Res. Rural Dev. 25 (10).

Azage T, Gebremedhin B, Hoekstra D, Belay B, Mekasha Y (2013). Smallholder dairy production and marketing systems in Ethiopia: IPMS experiences and opportunities for market-oriented development. IPMS (Improving Productivity and Market Success) of Ethiopian Farmers Project Working. P 31, ILRI, Nairobi, Kenya.

Belay D, Yisehak K, Janssens G (2012). Productive and reproductive performance of zebu $x$ Holstein-Friesian crossbred dairy cows in Jimma town, Oromia, Ethiopia. Glob. Vet. 8(1):67-72.

Belay D, Yisehak K, Janssens GP (2011). Analysis of constraints facing urban dairy farmers and gender responsibility in animal management in Jimma town. Libyan Agric. Res. Center J. Int. 2(4):155-160.

Belete A (2006). Studies on cattle milk and meat production in Fogera woreda: production systems, constraints and opportunities for development. MSc Thesis, Hawassa University, Hawassa, Ethiopia.

Berhanu GM, Adane H, Kahsay B (2009). Feed marketing in Ethiopia: Results of rapid market appraisal. Improving Productivity and Market Success (IPMS) of Ethiopian farmers project Working Paper 15. ILRI, Addis Ababa, Ethiopia.

Binyam K (2008). Cottage cheese production in Shashemane and the role of Rue (Rutachalepensis) and garlic (Allium sativum) on its quality and shelf life. MSc Thesis, Hawassa University, Hawassa, Ethiopia.

Central Agricultural Census Commission (CACC) 2003. Ethiopian Agricultural sample enumeration, 2001/02. Results for Southern nations, nationalities and peoples regional state.Statistical report on livestock and farm implements. Part IV. Addis Ababa, Ethiopia.

Central Statistical Agency (CSA) (2012). Agricultural sample survey. Vol. II. Report on livestock and livestock characteristics. Statistical Bulletin 582, Addis Ababa.

Dereje S, Yoseph M (2014). Evaluation of crossbred heifer calves rearing practices and growth performance in urban and peri-urban dairy systems of Sebeta woreda, Oromia. Ethiopian J. Anim. Prod.
$16(2): 121-132$

Derese $T$ (2008). Present situation of urban and peri-urban milk production and quality of raw milk produced in west Shewa zone, Oromia region, Ethiopia. MSc Thesis, Haramaya University, Haramaya, Ethiopia.

FAO (Food and Agriculture Organization of the United Nations) (2008). Country report. FAO (Food and Agriculture Organization of the United Nations). Addis Ababa, Ethiopia.

FAO (Food and Agriculture Organization of the United Nations) (2011). National workshop on Innovations, Actors and Linkage in the dairy value chain in Ethiopia. Proceedings of a National Stalkholder workshop held at Food and Agriculture Organization of the United Nations Sub Regional Office for Eastern Africa, 28 May 2010. Addis Ababa, Ethiopia.

Fekede F, Adugna T, Andnet D, Temesgen A, Diriba G, Alan D (2014). Assessment of livestock feed production and utilization systems and analysis of feed value chain in Jeldu district, Ethiopia. International Livestock Research, Addis Ababa, Ethiopia. Available at: https://cgspace.cgiar.org/handle/10568/56933

Gebremedhin A (2007). Major animal health problems of market oriented livestock development in AtsbiWomberta woreda, Tigray regional state. MSc Thesis, Addis Ababa University, Addis Ababa, Ethiopia.

Getachew E (2002). An assessment of feed resources, their management and impact on livestock productivity in the Ginch watershed area.MSc Thesis, Haramaya University, Haramaya, Ethiopia.

Gifawosen T, Alemu G/W, Jaya P (2003). Study on reproductive efficiency of Boran and its crosses at Holetta research farm: Effect of genotype, management and environment. Ethiopian J. Anim. Prod. 3(1):1607-3835.

Gizaw K, Habatamu A, Sisay E, Tesfaye M, Tegegn G, Birhanu $S(2012)$. Enhancing the productivity and profitability of crossbred and local cows in urban and peri urban centers of Bako and Nekemt, proceedings of the $19^{\text {th }}$ annual conference of Ethiopian Society of Animal Production, 15-17 December 2011. Addis Ababa, Ethiopia.

Haile W/A, Zelalem Y, Yosef T/G (2012). Challenges and opportunities of milk production under different urban dairy farm sizes in Hawassa City, Southern Ethiopia. Afr. J. Agric. Res. 7(26): 3860-3866.

Ibrahim N, Abraha A, Mulugeta S (2011). Assessment of reproductive performances of crossbred dairy cattle (Holstein Friesian $\times$ Zebu) in Gondar town. Glob. Vet. 6:561-566.

Juyal PD, Bal MS, Singla LD (2011). Economic impact, diagnostic investigations and management of protozoal abortions in farm animals. In: All India SMVS' Dairy Business Directory 11:39-46.

Kassahun A, Synman HA, Smit GN (2008). Impact of rangeland degradation on the pastoral production systems, livelihoods and perceptions of the Somali pastoralists in Eastern Ethiopia. J. Arid Environ. 72:1265-1281.

Kuastros M (2007). Major animal health problems of market oriented livestock development in Alaba woreda, southern nation nationalities and peoples region. MSc Thesis, Addis Ababa University, Addis Ababa, Ethiopia.

Kumar N, Eshetie A, Gebrekidan B, Gurmu EB (2014). Reproductive performance of indigenous and Holstein Friesian crossbred dairy cows in Gondar, Ethiopia. IOSR J. Agric. Vet. Sci. 7(1):50-61.

Lemma $F$ (2004). Assessment of butter quality and butter making efficiency of new churns compared to smallholders' butter making techniques in East Shewa Zone of Oromia. MSc Thesis, Harmaya University, Haramaya, Ethiopia.

Lemma F, Trivedi MM, Bekele T (2012). Adoption of improved dairy husbandry practices and its relationship with the socio-economic characteristics of dairy farmers in Ada'a district of Oromia State, Ethiopia. J. Agric. Exten. Rural Dev.4(14):392-395.

Lobago F (2007). Reproductive and lactation performance of dairy cattle in the Oromia central highlands of Ethiopia. PhD Dissertation, Swedish University of Agricultural sciences, Uppsala, Sweden.

Markos T (2006). Productivity and health of indigenous sheep breeds and crossbreds in the central Ethiopian highlands. PhD Dissertation, Swedish University of Agricultural Sciences Uppsala, Seweden.

Masama E, Kusina NT, Sibanda S, Majoni C (2003). Reproductive and lactation performance of cattle in a smallholder dairy system in 
Zimbabwe. Trop. Anim. Health Prod. 35:117-129.

MoA and ILRI (Ministry of Agriculture and International Livestock Research Institute) (2013). Dairy value chain vision and strategy for Ethiopia. Addis Ababa, Ethiopia: Ministry of Agriculture and International Livestock Research Institute. Addis Ababa, Ethiopia.

MOARD (Ministry of Agriculture and Rural Development) (2007). Livestock Development Master Plan Study. Phase I Report - Data Collection and Analysis. Addis Ababa, Ethiopia.

Mohammed A, Ehui S, Assefa Y (2004). Dairy Development in Ethiopia EOTD discussion Paper no. 123. International Food Policy Research Institute. Washington D.C.

Mohammed YK, deWaal HO (2009). Herd management, milk production and reproduction of urban dairy farms in Harar milk-shed. Ethiop. J. Anim. Prod. 9(1):57-75.

Mulugeta A, Belayeneh A (2013). Reproductive and lactation performances of dairy cows in Chacha town and nearby selected kebeles, North Shoa Zone, Amhara Region, Ethiopia. World J. Agric. Sci. 1(1):008-017.

Mustefa A (2012). Value chain and quality of milk in Sululta and Welmera woredas, Oromia special zone surrounding Addis Ababa, Ethiopia. MSc Thesis, Addis Ababa University, Addis Ababa, Ethiopia.

Negussie G (2006). Characterization and evaluation of urban dairy production system of Mekele city, Tigray Region, Ethiopia. MSc Thesis, Hawassa University, Hawassa, Ethiopia.

Radostits OM, Leslie KE, Fetrow J (1994). Maintenance of reproductive efficiency of dairy cattle. In: herd health: food animal production Medicine $2^{\text {nd }}$ edition. Philadelphin: W.B. Saundrs Company.

Ruiz-Sanchez R, Blake RW, Castro-Gamez HM, Sanchez F, Montaldo $\mathrm{HH}$, Castillo-Juarez H (2007). Changes in the association with between milk yield and age at first in Holstein cows with herd environment level for milk yield. J. Dairy Sci. 90:4830-4834.

Samson G, Zelalem Y, Sandip B (2012). Assessment of quality and marketing of milk and milk products in the central highlands of Ethiopia. Lambert Academic Publishing. Saarbrucken, Germany.

Shiferaw Y, Tenhagn B, Bekana M, Kassa T (2003). Reproductive performance of crossbred Dairy cows in different production systems in the central Highlands of Ethiopia. Trop. Anim. Health Prod. 25:551561.

Sintayehu Y, Fekadu B, Azage T, Berhanu G/M (2008). Dairy production, processing and marketing systems of Shashemene Dilla area, South Ethiopia. IPMS (Improving Productivity and Market Success) of Ethiopian Farmers Project Working Paper 9. ILRI (International Livestock research Institute), Addis Ababa, Ethiopia. Available at: https://cgspace.cgiar.org/handle/10568/485

Solomon A, Kelay B, Merga B, Fikre L (2009). Milk yield and reproductive performance of dairy cattle under smallholder management system in North Eastern Amhara Region, Ethiopia. Trop. Anim. Health Prod. 41:1597-1604.

Solomon K (2010). Characterization of market oriented small holder dairying and performance evaluation of dairy cooperatives in Tiyo woreda, Arsi zone of Oromia regional state. MSc Thesis, Hawassa University, Hawassa, Ethiopia.
Tefera M (2010). Food security attainment role of urban agriculture: a case study from Adama town, central Ethiopia. J. Sustainable Dev. Afr. 12:223-224.

Tesfahiwot Z (2004). Major Health problem of livestock in the Yerer water shed, Adaliben woreda, South eastern Shewa. MSc Thesis, Addis Ababa University, Addis Ababa, Ethiopia.

Wanapat M, Chanthakhoun V (2011). Food-feed-systems for smallholder livestock farmers. Successes and failures with animal nutrition practices and technologies in developing countries $\mathrm{p} 69$.

Yifat D, Kelay B, Bekana M, Lobago F, Gustafsson H, Kindahl H (2009). Study on reproductive performance of crossbred dairy cattle under smallholder conditions in and around Zeway, Ethiop. Livest. Res. Rural Dev. 21(6).

Yitaye A (2008). Characterization and analysis of urban and peri-urban dairy system in the northern western Ethiopia highlands. Doctoral dissertation, Boku University of Natural Resource and Applied Life Science, Veinna, Austrial.

Yoseph M, Azage T, Alemu Y (2003). Evaluation of the general farm characteristics and dairy herd structure in urban and peri-urban dairy production systems in Addis Ababa Milk Shed. In: Yilma Jobre and Getachew Gebru (Ed.), Proceedings of the $10^{\text {th }}$ annual conference of the Ethiopian society of animal production, 22-24 August 2002, Addis Ababa, Ethiopia.

Zelalem Y, Emannuelle GB, Ameha S (2011). A Review of the Ethiopian Dairy Sector. Ed. Rudolf Fombad, Food and Agriculture Organization of the United Nations, Sub-Regional Office for Eastern Africa (FAO/SFE), Addis Ababa, Ethiopia. 